\title{
Human Acid-Labile Subunit Deficiency: Clinical, Endocrine and Metabolic Consequences
}

\author{
Horacio M. Domenéa Vivian Hwa ${ }^{g}$ Jesús Argente ${ }^{b}$ Jaan M. Wit ${ }^{d}$ \\ Cecilia Camacho-Hübner ${ }^{c}$ Héctor G. Jasper ${ }^{a}$ Jesús Pozo ${ }^{b}$ \\ Hermine A. van Duyvenvoorde ${ }^{d-f}$ Shoshana Yakar ${ }^{\text {h }}$ \\ Olga V. Fofanova-Gambettig Ron G. Rosenfeld ${ }^{g}$ \\ on behalf of The International ALS Collaborative Group
}

${ }^{a}$ Centro de Investigaciones Endocrinológicas (CEDIE-CONICET), Hospital de Niños R. Gutiérrez, Buenos Aires,

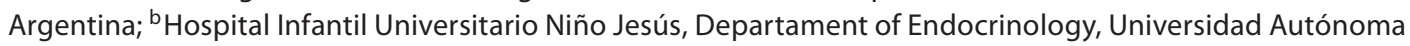
de Madrid, Departament of Pediatrics y CIBER Fisiopatología, Obesidad y Nutrición, Instituto de Salud Carlos III, Madrid, Spain; ' Pediatric Endocrinology, Women and Child Health, Karolinska Institute, Stockholm, Sweden; Departments of d Pediatrics, ${ }^{e}$ Endocrinology and Metabolism, and ${ }^{\mathrm{f} C l i n i c a l}$ Genetics, Leiden University Medical Center, Leiden, The Netherlands; ${ }^{9}$ Department of Pediatrics, Oregon Health and Science University, Portland, Oreg., and hEndocrine Divisions, Mount Sinai School of Medicine, New York, N.Y., USA

\section{Key Words}

Acid-labile subunit $\cdot$ Insulin-like growth factor-I . Insulin-like growth factor binding protein - Growth hormone insensitivity $\cdot$ Insulin insensitivity $\cdot$ IGFALS gene mutations

\begin{abstract}
The majority of insulin-like growth factor (IGF)-I and IGF-II circulate in the serum as a complex with the insulin-like growth factor binding protein (IGFBP)-3 or IGFBP-5, and an acid-labile subunit (ALS). The function of ALS is to prolong the half-life of the IGF-I-IGFBP-3/IGFBP-5 binary complexes. Fourteen different mutations of the human IGFALS gene have been identified in 17 patients, suggesting that ALS deficiency may be prevalent in a subset of patients with extraordinarily low serum levels of IGF-I and IGFBP-3 that re-
\end{abstract}

main abnormally low upon growth hormone stimulation. Postnatal growth was clearly affected. Commonly, the height standard deviation score before puberty was between -2 and -3 , and approximately 1.4 SD shorter than the midparental height SDS. Pubertal delay was found in $50 \%$ of the patients. Circulating IGF-II, IGFBP-1, -2 and -3 levels were reduced, with the greatest reduction observed for IGFBP-3. Insulin insensitivity was a common finding, and some patients presented low bone mineral density. Human ALS deficiency represents a unique condition in which the lack of ALS proteins results in the disruption of the entire IGF circulating

H.M.D. and H.G.J. are members of the Sociedad Latino-Americana de Endocrinología Pediátrica (SLEP); J.A., J.M.W., C.C.-H., J.P., O.V.F.-G., and R.G.R. are members of the European Society for Paediatric Endocrinology (ESPE).

\section{KARGER}

Fax +41613061234 E-Mail karger@karger.ch www.karger.com
(C) 2009 S. Karger AG, Basel

0301-0163/09/0723-0129\$26.00/0

Accessible online at:

www.karger.com/hre
Horacio M. Domené

Centro de Investigaciones Endocrinológicas (CEDIE-CONICET)

División de Endocrinología, Hospital de Niños R. Gutiérrez

Gallo 1330, Buenos Aires 1425 (Argentina)

Tel. +54 114963 5931, Fax +54 114963 5930, E-Mail hdomene@cedie.org.ar 
system. Despite a profound circulating IGF-I deficiency, there is only a mild impact on postnatal growth. The preserved expression of locally produced IGF-I might be responsible for the preservation of linear growth near normal limits.

Copyright $\odot 2009$ S. Karger AG, Basel

\section{Background}

The insulin-like growth factor (IGF) system, consisting of 2 ligands (IGF-I and IGF-II), 2 receptors (IGF-I receptor and IGF-II receptor) and 6 high-affinity IGF binding proteins (IGFBPs), plays a critical role in mammalian growth as repeatedly demonstrated in human case studies and rodent models. IGFs are highly homologous growth factors that are structurally similar to insulin. Interactions of IGFs with the IGF-I receptor result in a cascade of signaling events leading to critical endocrine, paracrine and autocrine effects on growth, differentiation and metabolism of normal as well as malignant cells [1]. IGF-II can also bind to the IGF-II receptor, a mannose-6-phosphate receptor which serves predominantly as a scavenger receptor.

In humans, IGFs are ubiquitously expressed and produced throughout prenatal and postnatal life. Targeted disruption of the IGF1 gene in rodent models [2], as well as mutations identified in the IGF1 gene in 2 well-characterized human cases, have been associated with intrauterine growth retardation and severe postnatal growth failure $[3,4]$. The severe or total lack of functional IGF-I from the time of conception also results in sensorineural deafness and mental retardation, suggesting that IGF-I is also essential for several critical embryonic developmental processes. The biological significance of IGF-II is less well characterized in humans, although it is of note that IGF-II concentrations are higher than those for IGF-I in utero and in sera of children $[5,6]$.

IGF-I (and IGF-II) circulates in the serum in complex with IGFBP-3 or IGFBP-5, and an acid-labile subunit (ALS) [7]. All 3 components are dramatically reduced in clinical conditions of growth hormone $(\mathrm{GH})$ deficiency and GH insensitivity, indicating the critical role of the GH-GHR-JAK-STAT pathway in the production of each component of the ternary complex [8]. When the first case of an inactivating mutation in the gene encoding the ALS protein (the IGFALS gene) was found, which was associated with short stature, insensitivity to GH and abnormally low serum IGF-I and IGFBP-3 levels, it provided direct support for the importance of ALS in the main- tenance of normal serum IGF-I and IGFBP-3 levels [9]. The number of mutations identified in the IGFALS gene has rapidly increased since the first described case, suggesting that ALS deficiency may be prevalent in a subset of patients that have extraordinarily low serum levels of IGF-I and IGFBP-3, even upon GH stimulation. This review will summarize insights gained in human growth and metabolism as a consequence of ALS deficiency.

\section{Role of the ALS}

ALS is an $85-\mathrm{kDa}$ glycoprotein that is produced almost exclusively by the liver and secreted into the circulation. The mature ALS protein belongs to the superfamily of leucine-rich repeats, a family of proteins characterized by their ability to participate in protein-protein interactions [10]. Molecular modeling of the ALS protein predicted 20 leucine-rich repeats motifs spanning $75 \%$ of the mature protein, arranged in a donut-like shape and flanked by $\mathrm{N}$ and $\mathrm{C}$-terminal regions that contain short cysteine-rich segments [10]. The protein surface contains charged residues, and while charged residues are relatively evenly distributed on the outer regions of the domain, the center hole of the donut is notably lined with large regions of electronegative surfaces. This, together with the negatively charged N-linked carbohydrates on the ALS protein, may provide the necessary electrostatic potential to interact with the IGF-I-IGFBP-3 binary complex $[10,11]$.

The well-established function of ALS is to prolong the half-life of the IGF-IGFBP-3/IGFBP-5 binary complexes, as ALS has no affinity for free IGF-I, IGF-II or uncomplexed IGFBP-3 and IGFBP-5 [7]. There is little evidence of other biological functions of ALS, although it is interesting that the recently identified fly ortholog of the mammalian ALS, the Drosophila dALS, was shown to regulate carbohydrate and fat metabolism, as well as growth [12]. In rodents, genetic targeted ablation of the IGFALS gene appeared to increase sensitivity to insulin [13]. Hence, it is of note that some of the subjects severely deficient in ALS presented with phenotypes suggestive of abnormal carbohydrate metabolism (see below). The mechanism(s) for this association remains unknown.

\section{The IGFALS ${ }^{--}$(ALS Knockout) Mouse Model}

Inactivation of the IGFALS gene in mice, which results in the complete absence of circulating ALS, produced mice that were only modestly growth deficient (13-20\% 
Table 1. Gestational age and birth size

\begin{tabular}{llllll}
\hline $\begin{array}{l}\text { Case } \\
\text { No. }\end{array}$ & $\begin{array}{l}\text { Gestational } \\
\text { age, weeks }\end{array}$ & $\begin{array}{l}\text { Length at } \\
\text { birth, cm }\end{array}$ & $\begin{array}{l}\text { Length at } \\
\text { birth, SDS* }\end{array}$ & $\begin{array}{l}\text { Weight at } \\
\text { birth, g }\end{array}$ & $\begin{array}{l}\text { Weight at } \\
\text { birth, SDS* }\end{array}$ \\
\hline 1 & NA & 47 at 1 week & NA & 2,500 at 1 week & NA \\
6 & 40 & 50 & -0.22 & 3,300 & -0.18 \\
7 & 40 & - & - & 3,300 & -0.18 \\
8 & 40 & - & - & 2,650 & -1.78 \\
11 & NA & - & - & 2,000 & NA \\
12 & 31 & - & - & $<1,400$ & $<-0.62$ \\
13 & 40 & 47 & -1.50 & 2,380 & -2.23 \\
14 & 40 & 53 & +1.06 & 2,940 & -1.31 \\
15 & 40 & 53 & +1.2 & 3,540 & -0.08 \\
16 & 40 & & & 3,060 & -1.87 \\
\hline
\end{tabular}

* Birth length and weight SDS were calculated according to Niklasson et al. [16] (case 12), Sobradillo et al. [17] and Carrascosa et al. [18] (cases 6-8), and Wikland et al. [19] (cases 13-16). NA = Not available.

smaller at 10 weeks) despite a 62 and $88 \%$ reduction of IGF-I and IGFBP-3 plasma levels, respectively [14, 15]. The IGF-I and IGFBP-3 deficiencies were likely a result of increased turnover, as their synthesis in the liver and kidneys remained normal. Interestingly, analysis of glucose metabolism in the ALS knockout mice revealed that although fasting plasma levels of glucose, insulin and nonesterified fatty acids were normal [14], a faster glucose clearance during intraperitoneal glucose tolerance tests was observed, as was a trend towards higher whole body utilization and muscle uptake of glucose during hyperinsulinemic-euglycemic clamping experiments [13]. Altogether, these results suggested that the ALS knockout mice had a higher sensitivity to insulin compared to controls [13]. In addition, the ALS knockout mice also presented retardation of bone development, characterized by a reduction in femoral periosteal circumference and cortical thickness, and a lower total bone mineral density (BMD). A 7.5\% reduction in femoral length was noted, with a $24 \%$ reduction in femoral cortical bone volume. The ALS knockout mice also showed a $37 \%$ reduction in trabecular bone [15]. It is not clear, at present, if these physiological alterations are a direct or indirect result of a total ALS deficiency.

\section{Human ALS Deficiency}

\section{Auxological Characteristics}

The ALS mutations identified to date have been described in short children and adults. It is possible that the association of ALS deficiency with growth retardation represents, at least in part, some degree of ascertainment bias, as serum concentrations of the various components of the IGF system are not measured routinely in individuals of normal stature. It is uncertain whether prenatal growth is affected by an IGFALS gene defect, as birth weights together with data on gestational age were reported in only 8 cases, but the low mean birth weight (-1.0 standard deviation score (SDS), range from -2.23 to -0.08 SDS) suggests that there may be some effect (table 1). Birth length could be analyzed in only 4 cases, and appeared to be normal. However, postnatal growth was clearly affected by mutations in the IGFALS gene (tables 2 and 3). In the majority of cases, height SDS before and during puberty was between -2 and -3 , and approximately 1.4 SD shorter than the midparental target height SDS (table 3). Of the 12 male patients for whom data were available, 6 clearly had a delayed pubertal onset $(>14$ years), with puberty starting in the remaining male patients around 13 years of age. Although these results are not definitive, it would appear that an ALS defect in males may be associated with delayed puberty, with an average onset at approximately 14 years of age. This may explain why, in most of the cases, adult height SDS was higher than prepubertal height, but still 1.0 SD lower than the midparental target height SDS. The only affected female for whom pubertal data were available, had her menarche at 13 years of age.

No discernable aberrance in the pubertal growth spurt pattern emerged from the reported cases (table 2). In the first reported case, the growth spurt was well documented and considered normal [20], as were the 2 boys with delayed puberty described by Domené et al. [21] and 2 of 
Table 2. Clinical characteristics at diagnosis in patients with IGFALS gene mutations

\begin{tabular}{lllllllll}
\hline $\begin{array}{l}\text { Case } \\
\text { No. }\end{array}$ & Sex & $\begin{array}{l}\text { CA } \\
\text { years }\end{array}$ & $\begin{array}{l}\text { BA/CA } \\
\text { ratio }\end{array}$ & $\begin{array}{l}\text { Height } \\
\text { SDS }\end{array}$ & $\begin{array}{l}\text { Weight } \\
\text { SDS }\end{array}$ & $\begin{array}{l}\text { BMI } \\
\text { SDS }\end{array}$ & $\begin{array}{l}\text { Puberty } \\
\text { onset, years }\end{array}$ & $\begin{array}{l}\text { Reference } \\
\text { No. }\end{array}$ \\
\hline 1 & M & 14.6 & 0.86 & -2.05 & -2.34 & -1.03 & 15.7 & 9 \\
2 & M & 12.1 & 0.99 & -2.90 & -1.08 & 1.05 & 13.0 & 27 \\
$3^{*}$ & M & 15.3 & 0.92 & -2.00 & -0.25 & 1.22 & 16.0 & 21 \\
$4^{*}$ & M & 19.6 & - & -0.50 & -1.97 & 2.08 & 16.9 & 21 \\
$5^{*}$ & F & 15.4 & - & -1.00 & -0.72 & -0.17 & 13.0 & 21 \\
6 & M & 4.5 & 0.67 & -2.37 & -1.64 & -0.87 & 12.4 & 22 \\
7 & M & 4.7 & 0.59 & -3.90 & -2.30 & -0.72 & 13.5 & 22 \\
8 & M & 15.0 & 0.83 & -2.55 & -2.02 & -1.22 & 14.5 & 22 \\
$9^{*}$ & M & 14.6 & - & -4.20 & -3.68 & 1.20 & 14.0 & 23 \\
$10^{*}$ & M & 6.8 & - & -3.00 & -2.45 & -1.00 & 13.0 & 23 \\
$11^{*}$ & M & 4.2 & 1.07 & -3.20 & -2.71 & -0.30 & 13.0 & 23 \\
12 & M & 6.7 & 0.82 & -2.80 & 0.25 & - & 10.5 & 24 \\
13 & $\mathrm{~F}$ & 4.1 & 1.00 & -2.14 & -3.40 & -2.80 & - & 24 \\
14 & $\mathrm{M}$ & 15.2 & 0.73 & -3.17 & -2.33 & -1.66 & - & 24 \\
15 & $\mathrm{M}$ & 12.7 & 0.91 & -2.87 & -2.4 & -0.80 & - & 24 \\
16 & $\mathrm{M}$ & 10.6 & - & -2.80 & -3.63 & -2.13 & - & 26 \\
17 & $\mathrm{M}$ & 13.4 & - & -3.20 & - & - & - & 26 \\
\hline
\end{tabular}

* Patients are siblings.

Table 3. Prepubertal, pubertal and adult height of the ALS-deficient cases and parental height, expressed as SDS, for local or ethnic standards

\begin{tabular}{|c|c|c|c|c|c|c|c|c|c|}
\hline $\begin{array}{l}\text { Case } \\
\text { No. }\end{array}$ & Sex & $\begin{array}{l}\text { Prepubertal } \\
\text { HSDS }\end{array}$ & $\begin{array}{l}\text { Adolescent } \\
\text { HSDS }\end{array}$ & Adult HSDS & $\begin{array}{l}\text { HSDS } \\
\text { father }\end{array}$ & $\begin{array}{l}\text { HSDS } \\
\text { mother }\end{array}$ & $\begin{array}{l}\text { Prepubertal } \\
\text { HSDS - } \\
\text { MPH SDS }\end{array}$ & $\begin{array}{l}\text { Adult } \\
\text { HSDS - } \\
\text { MPHSDS }\end{array}$ & $\begin{array}{l}\text { Pubertal onset } \\
\text { (G2) in males } \\
\text { or menarche in } \\
\text { females }\end{array}$ \\
\hline 1 & M & $-2.05(14.6)$ & $-1.63(17.7)$ & $-0.78(21.3)$ & & & & & 15.7 (D) \\
\hline 2 & M & $-2.90(12.1)$ & $-2.10(15.5)$ & & -2.00 & -2.80 & -0.50 & & 13.0 \\
\hline 3 & M & $-2.00(15.3)$ & & $-0.50(18.0)$ & +1.50 & -0.93 & -1.71 & -0.21 & 16.9 (D) \\
\hline 4 & M & $-1.91(10.8)$ & & $-0.50(19.6)$ & +1.50 & -0.93 & -1.62 & -0.21 & 16.0 (D) \\
\hline 5 & $\mathrm{~F}$ & $-1.06(9.5)$ & $-1.00(15.4)$ & & +1.50 & -0.93 & -0.77 & & 13.0 \\
\hline 6 & M & $-2.37(4.5)$ & $-2.55(12.4)$ & $-2.53(16.6)$ & -0.10 & +0.65 & -2.62 & -2.81 & 12.4 \\
\hline 7 & M & $-3.90(4.7)$ & $-2.97(13.6)$ & & -2.30 & -0.55 & -2.47 & & 13.5 \\
\hline 8 & M & & $-2.55(15.0)$ & $-1.32(20.3)$ & -0.43 & -0.40 & & -0.91 & 14.5 (D) \\
\hline 9 & M & & $-4.20(14.6)$ & $-4.20(27.2)$ & -3.20 & -3.40 & & -0.90 & 14.0 (D) \\
\hline 10 & M & $-3.00(6.8)$ & & $-3.60(21.5)$ & -3.20 & -3.40 & +0.30 & -0.30 & 13.0 \\
\hline 11 & M & $-3.20(4.2)$ & $-4.40(17.0)$ & & -3.20 & -3.40 & +0.10 & & 13.0 \\
\hline 12 & M & $-2.91(6.7)$ & $-2.62(12.0)$ & & NA & NA & & & 10.5 \\
\hline 13 & $\mathrm{~F}$ & $-2.14(4.1)$ & & & +0.30 & -2.13 & -1.22 & & \\
\hline 14 & M & $-3.00(15.2)$ & & & -1.35 & -0.09 & -2.28 & & \\
\hline 15 & M & $-2.70(12.5)$ & & & +0.85 & -1.68 & -2.36 & & \\
\hline 16 & M & $-2.80(10.6)$ & & & 0.00 & -2.00 & -1.80 & & \\
\hline 17 & M & $-3.20(13.4)$ & -3.80 & -3.80 & -1.80 & -1.80 & -1.40 & -2.00 & 14.0 (D) \\
\hline Mean & & -2.61 & -2.78 & -2.15 & -0.78 & -1.38 & -1.41 & -1.05 & 13.9 (males) \\
\hline
\end{tabular}

Values in parentheses represent age in years, except where otherwise noted. HSDS = Height SDS; MPHSDS = midparental height SDS; G2 = Tanner stage 2; D = delayed puberty. 
the Spanish cases [22]. In contrast, the 3 Kurdish males appeared to have a poor pubertal growth spurt [23].

In an effort to improve growth, GH therapy was provided for some of the patients. While the length of treatment ranged from 6 months to more than 2 years, growth response, on the whole, was poor. For the patient who was given $\mathrm{GH}$ for 6 months, the change in growth velocity ( 6.2 vs. $4.6 \mathrm{~cm} /$ year, in midpuberty) was considered low [9]. Case 3 was treated with GH for a total period of 17 months, beginning at 15.5 years of age, and the response was considered insufficient. It should be noted that in the last half of this treatment, testosterone enanthate was added [21]. Case 8 was treated with GH from 15.5 to 18.8 years of age, but as this period coincided with the pubertal growth spurt, it was difficult to judge the efficacy of therapy [22]. In case $12, \mathrm{GH}$ was administered from 8.5 to 9.5 and 10 to 12 years of age. Between 10.5 and 12 years of age, a GnRH analogue was added to preserve growth potential during GH therapy. In both periods the growth response was considered insufficient, and from 12 years of age IGF-I therapy (Increlex; Tercica, Brisbane, Calif., USA) was started with the results pending [24]. Case 13 was treated with $\mathrm{GH}$ from 4.4 years of age onward, and the growth response appeared suboptimal [24]. It is of particular note in all these cases that IGF-I and IGFBP-3 concentrations remained strikingly low despite GH therapy. In summary, the efficacy of $\mathrm{GH}$ appears poor in patients carrying mutations in the IGFALS gene. In the few cases where testosterone was administered for delayed puberty, the effect was as expected in boys with constitutional delay of growth and puberty.

With respect to other growth parameters, weight-forheight (expressed as BMI) is generally normal. Head circumference was only reported in the 3 Kurdish males, where it was decreased in comparison to heterozygous and wild-type relatives [23].

It is noteworthy that the mean parental height is approximately 1.3 SDS lower than the population's mean (table 3). This suggests that heterozygosity for an ALS mutation may have a mild growth phenotype. Interestingly, in the family where the height of 3 homozygous cases could be compared with 5 heterozygous carriers and 5 wild-type relatives, height SDS was $-4.1,-2.3$ and -1.3 , respectively, although the differences between heterozygous carriers and wildtypes did not reach statistical significance [23]. Further studies are necessary to evaluate the effect(s) of IGFALS heterozygosity on growth.

\section{Spectrum of IGFALS Gene Mutations}

The human IGFALS gene maps to chromosome 16, location 16p13.3. The gene contains 2 exons, 97 and 1,987 bp in size, separated by a 1,235-bp intron. Whereas exon 1 encodes only the first 5 amino acids and the 1 st base of the codon corresponding to the 6th amino acid of the protein, exon 2 encodes the 2 last bases of codon 6 and the remaining 599 amino acids [25]. The signal peptide comprises the first 27 amino acids and the mature protein consists of 578 amino acids organized in 20 repeating leucine-rich domains of 24 amino acids, flanked by 2 amino- and carboxyl-terminal regions containing 13 cysteine residues [10]. The protein contains 7 asparagine residues that are potential glycosylation sites.

To date, at least 17 patients with complete ALS deficiency have been characterized at the molecular level (table 4) $[9,21-24,26,27]$. Only 2 are female, probably the result of a more frequent concern of parents for the height of their male offspring.

Fourteen different mutations of the human IGFALS gene have been identified in the 17 patients studied (table 4 , fig. 1). Eleven patients were found to be homozygous and 6 were compound heterozygous. In 2 separate families, 3 siblings were affected with the same mutations $[21,23]$. When the parents of the affected subjects were available for the characterization of the IGFALS gene, the results were consistent with an autosomal recessive pattern of inheritance. Consanguinity was present in 3 families including 5 patients ( 3 of them siblings), absent in 6 families including 8 patients ( 3 of them siblings) and unknown in the other 4 families.

Different types of mutations in the IGFALS gene have been reported, including missense, nonsense, deletion, duplication and insertion resulting in frameshift and premature stop codons, as well as 2 different in-frame duplication mutations leading to insertions of 3 extra amino acid residues (table 4, fig. 1). The majority of IGFALS gene mutations produced defects in the leucinerich repeat region of the protein: 7 missense, 1 nonsense, 2 frameshift and 2 in-frame duplication mutations. One frameshift mutation was detected in the region encoding the amino terminal flanking domain, and 1 missense mutation was detected in the region encoding the carboxyl-terminal flanking domain.

At present, all the described IGFALS gene mutations have resulted in either completely absent or barely detectable ALS levels as determined by ELISA, RIA or Western immunoblot using specific monoclonal antibodies directed against either the amino or the carboxyl terminus 


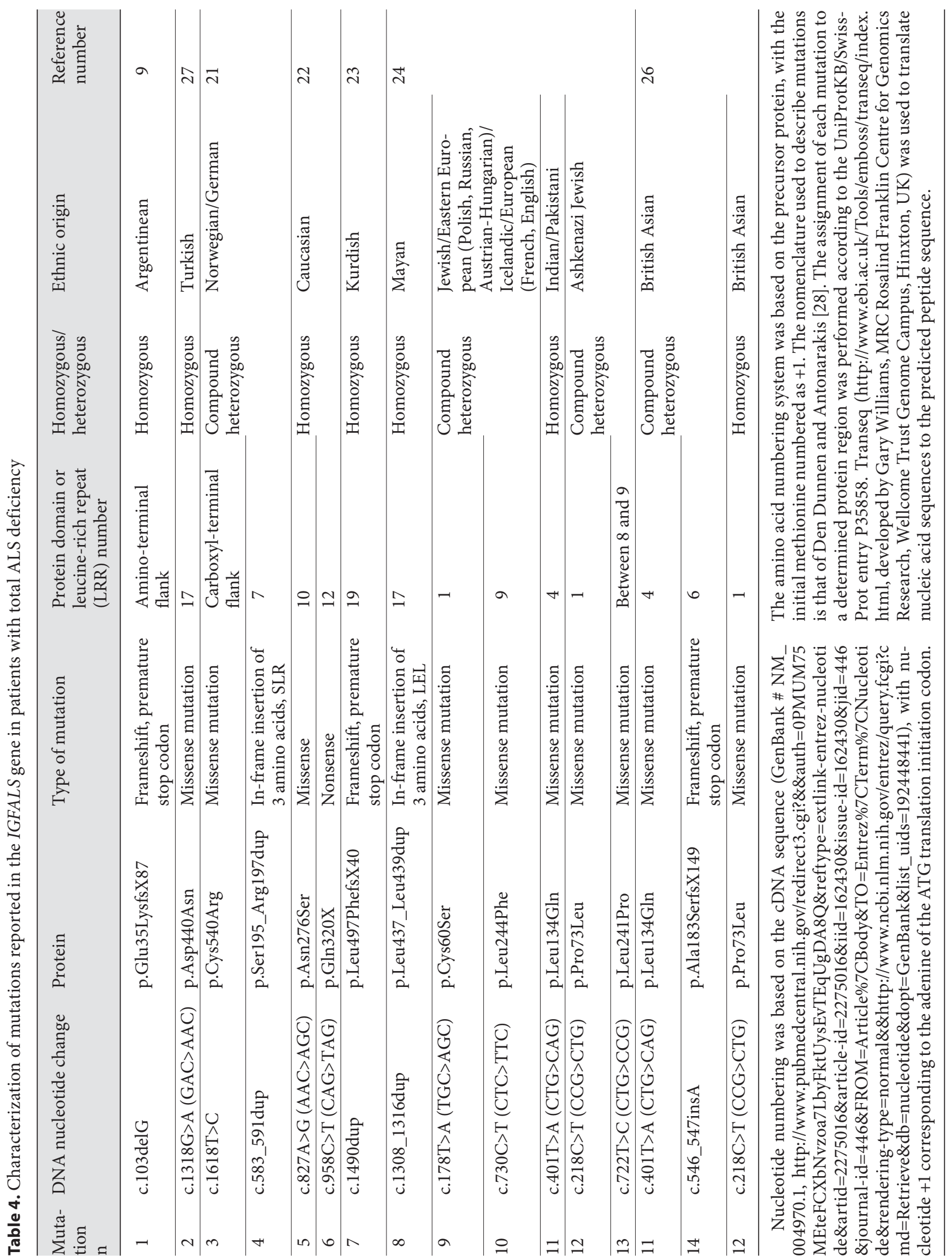


Fig. 1. Schematic representation of the ALS protein indicating the location of the 14 identified human mutations. Black: missense; red: frameshift, magenta: nonsense; blue: duplication (colors in online version only).

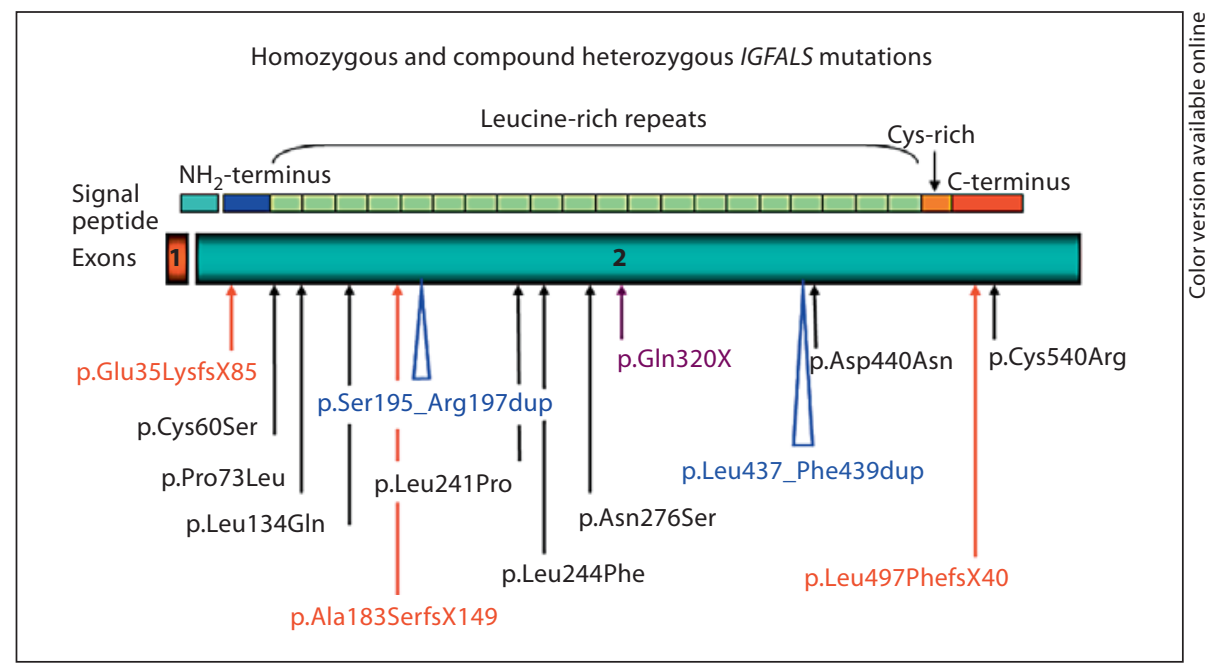

of the ALS protein. The lack of detectable ALS levels in sera from patients with these distinct mutations suggests that the mutated proteins are unable to be normally secreted, or that they are unstable and rapidly degraded after secretion. The in vitro expression of the $\mathrm{p}$.Asp440Asn (mature mutant peptide designated p.Asp413Asn-ALS [patient reported in 27]) indicated that this mutant ALS was inefficiently secreted, remaining trapped inside the cells [29]. The recombinant p.Asp440Asn protein also displayed a reduced ability for in vitro ternary complex formation when incubated with IGF-I and IGFBP-3, probably because the p.Asp440Asn substitution resulted in a new potential $\mathrm{N}$-glycosylation site and the disruption of the acidic internal surface, a proposed IGFBP-3 binding site $[27,29]$. In cases where in vitro ternary complex formation was investigated, serum samples from ALSdeficient patients could not form ternary complexes, indicating either the absence of a ALS protein or the lack of a bioactive form. The complete absence of an ALS protein in the circulation in patients homozygous or compound heterozygous for inactivating IGFALS mutations and the low to low-normal ALS levels in heterozygous carriers suggest that, in normal conditions, both alleles of IGFALS genes are expressed.

\section{Effect on the GH-IGF System}

Human ALS deficiency results in a peculiar form of IGF-I deficiency. Whereas circulating levels of IGF-I decrease dramatically $[9,20-24,26,27]$, local production, and presumably action, appears to be preserved. In addi- tion to IGF-I, other members of the circulating IGF system are also affected. Circulating IGF-II levels are reduced [20, 22-24], while IGFBP-3 levels are even more profoundly diminished. Levels of IGFBP-1 and -2 are reduced, although to a lesser extent (table 5) [20, 22-24].

The complete absence of ALS represents a unique situation leading to generalized deficiency of the circulating so-called 'endocrine IGF system', with the expression and action of the peripheral or autocrine/paracrine IGF system being preserved or even up-regulated due to normal or increased GH levels present in this alteration. Assuming that the various $\mathrm{GH}$ assays and standards are comparable, and assuming a conversion rate of $1 \mathrm{mg}=2 \mathrm{IU}$, the average $\mathrm{GH}$ peak in stimulation tests was $46 \mathrm{ng} / \mathrm{ml}$ (range $10-98 \mathrm{ng} / \mathrm{ml}, \mathrm{n}=12$ ). When the nocturnal 12-hour spontaneous $\mathrm{GH}$ profile was investigated in the first described ALS-deficient patient, a moderate elevation of GH levels was found $(18.9 \pm 12.6 \mathrm{ng} / \mathrm{ml}$; reference values $4.5 \pm 1.4$ $\mathrm{ng} / \mathrm{ml}$ ) [9]. However, the elevation of GH levels in ALS deficiency appears to be less marked than that observed in patients with GH insensitivity, although in both cases they show a comparable reduction in IGF-I levels. These findings suggest that in ALS deficiency the local production of IGF-I is able to partially control GH secretion.

As indicated above, the main role of the ALS protein is to maintain the circulating IGF-I pool by the formation of a $150-\mathrm{kDa}$ ternary complex with IGF-I and IGFBP-3 or $-5[30,31]$, extending the IGF-I half-life up to more than $12 \mathrm{~h}[32,33]$ by preventing its passage to the extravascular compartment [34] and preserving both IGF-I and IGFBP3 from proteolysis. Given its abundant molar excess in the sera, its completely different primary and 3-dimensional 
Table 5. The IGF system in patients with IGFALS gene mutations

\begin{tabular}{|c|c|c|c|c|c|c|c|c|c|c|c|c|c|c|c|}
\hline \multirow{2}{*}{$\begin{array}{l}\text { Case } \\
\text { No. }\end{array}$} & \multirow[t]{2}{*}{ Sex } & \multirow{2}{*}{$\begin{array}{l}\text { Age } \\
\text { years }\end{array}$} & \multicolumn{2}{|l|}{ IGF-I } & \multicolumn{2}{|c|}{ Free IGF-I } & \multicolumn{2}{|l|}{ IGF-II } & \multirow{2}{*}{$\begin{array}{l}\text { ALS } \\
\mu \mathrm{g} / \mathrm{ml}\end{array}$} & \multicolumn{2}{|c|}{ IGFBP-1 } & \multicolumn{2}{|c|}{ IGFBP-2 } & \multicolumn{2}{|c|}{ IGFBP-3 } \\
\hline & & & $\mathrm{ng} / \mathrm{ml}$ & SDS & $\mathrm{ng} / \mathrm{ml}$ & SDS & $\mathrm{ng} / \mathrm{ml}$ & SDS & & $\mathrm{ng} / \mathrm{ml}$ & SDS & $\mathrm{ng} / \mathrm{ml}$ & SDS & $\mu \mathrm{g} / \mathrm{ml}$ & SDS \\
\hline 1 & $\mathrm{M}$ & 14.6 & 31 & -5.3 & 0.68 & -0.64 & 71 & -5.5 & $<0.5$ & 14.1 & -2.4 & 43 & -1.6 & 0.22 & -9.7 \\
\hline 2 & M & 13.9 & 70 & -4.6 & 0.21 & & & & $<0.4$ & & & & & 0.49 & -7.0 \\
\hline $3^{*}$ & $\mathrm{M}$ & 18.0 & 10 & -10.4 & & & & & $<0.5$ & & & & & 0.39 & -15.5 \\
\hline $4^{*}$ & M & 19.6 & 8 & -11.2 & & & & & $<0.5$ & & & & & 0.38 & -15.7 \\
\hline $5^{*}$ & $\mathrm{~F}$ & 15.4 & 14 & -9.3 & & & & & $<0.5$ & & & & & 0.43 & -14.9 \\
\hline 6 & $\mathrm{M}$ & 4.5 & 15 & -3.2 & 0.19 & -1.0 & 129 & -3.6 & $<0.5$ & $<0.4$ & - & 142 & -1.2 & 0.70 & -3.6 \\
\hline 7 & $\mathrm{M}$ & 4.7 & 11 & -3.8 & 0.09 & -1.8 & 126 & -3.3 & $<0.5$ & $<0.4$ & - & 111 & -1.8 & 0.75 & -3.9 \\
\hline 8 & $\mathrm{M}$ & 15.0 & 40 & -4.3 & & & & & $<0.5$ & $<0.4$ & - & 125 & -0.9 & $<0.5$ & $<-7.0$ \\
\hline $9^{*}$ & $\mathrm{M}$ & 27.2 & $<12$ & $<-7.2$ & & & 66 & -6.6 & $<0.1$ & 27 & & 67 & -2.5 & 0.09 & -18.2 \\
\hline $10^{*}$ & $\mathrm{M}$ & 21.5 & 13 & -7.4 & & & 55 & -6.8 & $<0.1$ & 12 & -1.5 & 95 & -1.8 & 0.09 & -18.5 \\
\hline $11^{*}$ & $\mathrm{M}$ & 17.0 & 29 & -5.6 & & & 49 & -6.7 & $<0.1$ & 9 & -2.2 & 69 & -3.0 & 0.10 & -17.6 \\
\hline 12 & $\mathrm{M}$ & 12.0 & 49 & -3.4 & & & & & $<1.0$ & & & & & 0.39 & -3.7 \\
\hline 13 & $\mathrm{~F}$ & 5.0 & 13 & -3.5 & & & & & $<1.0$ & & & & & 0.30 & -4.5 \\
\hline 14 & $\mathrm{M}$ & 15.5 & 24 & -4.7 & & & 130 & -4.6 & $<1.0$ & & & 105 & -3.5 & 0.30 & -4.1 \\
\hline 15 & $\mathrm{M}$ & 12.7 & 25 & -3.3 & & & 87 & -5.2 & $<1.0$ & & & 364 & 0.4 & 0.40 & -3.7 \\
\hline 16 & $\mathrm{M}$ & 6.5 & 33 & & & & & & 0.3 & & & & & 0.20 & \\
\hline 17 & $\mathrm{M}$ & 13.0 & 40 & & & & & & $<0.5$ & & & & & 0.40 & \\
\hline
\end{tabular}

SDS values were calculated on the basis of local references. * Patients are siblings.

spatial structure, and its relatively low affinity for binary IGF-IGFBP complexes (300- to 1,000-fold lower than that of IGFBP-3 for either IGF-I or IGF-II) [35], ALS has received much less attention in comparison with the other members of the circulating IGF system [7] as it was considered a redundant circulating protein with low binding affinity properties. However, while the targeted inactivation of individual IGFBPs in rodent models has little if any effect on the phenotype and the circulating IGF system [36], most likely due to some redundancy of function among the different IGFBPs, the ALS-knockout mouse exhibits a profound impact on the whole IGF system, with a marked reduction in IGF-I and IGFBP-3 levels (see above; 14). It is also remarkable that up to now, no other single IGFBP deficiency has been characterized in humans, perhaps because the presence of the remaining IGFBPs partially compensates for any selective IGFBP deficiency or absence. In contrast, the irreplaceable function of the ALS protein for the stabilization of the ternary complexes makes it impossible for these to be formed in its absence, which leads to the rapid clearance of IGF-I, IGF-II and IGFBP-3 from the circulation and their permanently reduced levels. Consequently, the reduction in IGF-I, IGF-II and IGFBP-3 found in ALS deficiency seems to result in the instability of these proteins and their increased turnover, rather than a defect in their synthesis.
In support of this hypothesis, a normal IGFBP-3 concentration was detected in media conditioned by primary dermal fibroblast cells established from an ALS-deficient patient [27]. Moreover, null ALS mice have a normal abundance of IGF-I mRNA in the liver and IGFBP-3 mRNA in the liver and kidneys [14].

The mechanism involved in the moderate IGFBP-1 and -2 deficiencies is less obvious. High levels of insulin, a common finding in ALS-deficient patients, are probably the result of some degree of insulin insensitivity and could be responsible for the repression of IGFBP-1 expression. Perhaps the same mechanism might explain the reduction in IGFBP-2 levels. Insulin is an important regulator of the hepatic synthesis of both IGFBP-1 and IGFBP-2 [37], but while the suppression of liver IGFBP-1 expression by insulin occurs at the transcriptional level [38], the effect on IGFBP-2 occurs at the translational lev$\mathrm{el}$, and the changes observed are not as rapid as those observed for IGFBP-1 [39]. The increased GH levels might also play a role, since in GH-deficient patients, IGFBP-2 levels are usually increased [40] and administration of GH decreases plasma IGFBP-2 in adult subjects with a normal caloric intake [41].

A remarkable effect of the absence of ALS is the predominant reduction of circulating IGFBP-3 levels compared with those of IGF-I. In GH-deficient and GH-in- 
sensitive patients, circulating IGF-I is more reduced than IGFBP-3, as IGFBP-3 is less dependent on GH than IGF-I. The predominant deficit of IGFBP-3 over IGF-I could therefore be a useful marker to direct the investigation of the etiology of short stature toward the diagnosis of ALS deficiency.

\section{Carbohydrate Metabolism}

Carbohydrate metabolism data were available in 11 of the 17 patients presented in this review. Fasting blood glucose levels were normal in these 11 patients $(87.7 \pm 7.3$ $\mathrm{mg} / \mathrm{dl}$; range $79-100)$. In 1 of the 4 patients that underwent an oral glucose tolerance test, slight glucose intolerance was suggested (glycemia at $120 \mathrm{~min}=149 \mathrm{mg} / \mathrm{dl}$ ). In all patients except 1 (homeostasis model assessment index = 2.9; basal insulin: $14 \mathrm{mU} / \mathrm{l})$, insulin insensitivity was suggested [42-44] by 1 or more of the criteria analyzed: fasting insulin levels $>15 \mathrm{mU} / 1$ (10 of 11 patients; mean \pm SD: $21.7 \pm 7.8 \mathrm{mU} / \mathrm{l}$; range: $10.9-32.4$ ); insulin peak post-oral glucose tolerance test $>150 \mathrm{mU} / \mathrm{l}$ ( 2 of 4 ; mean \pm SD: $191.2 \pm 96.0 \mathrm{mU} / \mathrm{l}$; range: $78.5-281)$; insulinemia at $120^{\prime}>75 \mathrm{mU} / \mathrm{l}$ ( 3 of 4 ; mean $\pm \mathrm{SD}: 135.2 \pm$ $103.8 \mathrm{mU} / 1$; range: $44-279)$; or homeostasis model assessment index $>3$ ( 9 of 11 ; mean \pm SD: $4.3 \pm 1.9$; range: 2.1-7.8). Serum IGFBP-1 levels, an indirect indicator of insulin sensitivity [45], were very low or undetectable in all patients analyzed. Together, these data suggest that patients with congenital ALS deficiency demonstrate some degree of insulin insensitivity; however, the pathophysiological mechanisms involved are not clear. The increase in GH secretion, reduction in circulating IGF-I levels or the interaction between these factors could be involved, but the relationship between the GH axis and carbohydrate metabolism is complex and only partially understood. The diabetogenic properties of GH were first described in the 1930s when Houssay [46] reported that hypophysectomy reduced the hyperglycemia of experimental diabetes in dogs. Subsequent studies demonstrated that increased circulating GH levels result in hyperinsulinemia, insulin insensitivity and possibly carbohydrate intolerance or diabetes mellitus. In contrast, GH deficiency is associated with hypoinsulinemia, increased insulin sensitivity and decreased fasting glucose levels [47]. Although the metabolic consequences of altered GH levels on insulin sensitivity and action are well known, the underlying mechanisms involved are not. Multiple factors are most likely involved, including alterations in insulin sensitivity due to increased free fatty acids result- ing from the lipolytic effects of excess GH ('lipotoxic effect') $[48,49]$, postreceptor crosstalk between the insulin receptor and GH receptor signaling pathways [50], decreased expression of the insulin-sensitizing adipocytokines adiponectin and visfatin $[51,52]$ or the hyperinsulinemia induced by the excess GH that reduces the number of insulin receptors and alters their kinase activity [53]. Moreover, GH has stimulatory effects on insulin directly at the level of the $\beta$-cell, but prolonged exposure to excess GH results in $\beta$-cell failure followed by decreased insulin secretion and glucose tolerance, a feature resembling the long-term sequelae of altered glucose homeostasis in untreated acromegalic patients [54].

The slight increase in GH secretion found in patients with congenital ALS deficiency suggests that this is unlikely to be the only mechanism involved in their insulin insensitivity states. Recent data suggest that the IGFs may play an important role in carbohydrate metabolism, maintaining a balance between insulin and GH actions [55]. Important contributions to the clarification of the mechanisms of insulin and IGF-I actions have been provided by transgenic and knockout mouse models. The marked insulin insensitivity observed in the liver-specific IGF-I knockout mouse [56, 57], which suggests an important role for circulating IGF-I in glucose homeostasis, is blocked by deletion of the ALS gene [13]. However, findings in humans and mice cannot always be directly extrapolated. Although the ALS knockout mouse has a slight reduction in postnatal growth, no alterations in glucose metabolism or insulin insensitivity are found [13]; on the contrary, the ALS knockout mice appear to display an increased sensitivity to insulin [13].

Various studies have demonstrated that IGF-I can augment glucose uptake by peripheral tissues, decreasing blood glucose levels [55, 58], although to a much lesser degree than insulin. Given that the affinity of IGF-I for the insulin receptor is very low, it is thought that the majority of its metabolic effects are mediated through the IGF-I receptor. This receptor is not present in liver or adipose tissue [50], but is present in high concentrations in skeletal muscle, where IGF-I has been shown to induce glucose uptake [59]. Furthermore, as skeletal muscle expresses both insulin and IGF-I receptors, hybrid receptors (heterodimers of $1 \alpha \beta$-subunit of the insulin receptor and $1 \alpha \beta$-subunit of the IGF-I receptor) with a higher affinity for IGF-I than insulin could mediate IGF-I-stimulated glucose uptake in this tissue [60]. However, as IGFI can also decrease GH secretion, it is difficult to dissect the direct actions of IGF-I on carbohydrate metabolism from those induced by decreased GH secretion. Finally, 
IGF-I has also been shown to play a crucial role in the maintenance of insulin secretion and the development and survival of the $\beta$-cell population [61].

In conclusion, human subjects with ALS deficiency due to mutations in the IGFALS gene present low levels of IGF-I, IGFBP-3 and ALS, with moderate hyperinsulinemia and very low levels of IGFBP-1. The pathophysiological mechanisms explaining this hyperinsulinemia are still only partially understood.

\section{Bone Metabolism and Mineralization}

As ALS knockout mice have a low bone density $[15,62$, 63], one might expect patients with an ALS defect to have osteopenia. In fact, the first reported case had a marked reduction in BMD (-4.7 SDS) at 16 years of age, with a partial recovery upon completion of puberty (-2.1 SDS at 19 years of age) [64]. When 2 of the Kurdish cases presented with severely low BMD, 1 of them presenting with 2 fractures after minor trauma, the probability of an effect of ALS deficiency seemed to increase further. However, in this family a low BMD was also noticed in heterozygous and wild-type carriers, suggesting that the low BMD observed was independent of the ALS defect [23]. Further, BMD was normal in cases 2 (Dr. Haeusler, personal communication), 6 and 7 [21]. Information about the other cases are unknown. In summary, unlike in rodent models, an ALS defect in humans does not appear to be a cause of low BMD.

\section{Identification of Patients with an ALS Mutation}

Identification of patients with an ALS mutation is problematic, largely because the natural history of this condition remains uncertain. To some extent, this is the result of the inevitable ascertainment bias that has impacted the initial reports; specifically, serum concentrations of IGF-I, IGFBP-3 and, in particular, ALS are not commonly measured in children of normal height, so it is difficult to determine how prevalent this mutation may be in the normal population. It is already clear that some patients with homozygous or compound heterozygous mutations may have childhood and/or adult heights within the normal range. It is also likely that some children labeled as 'GH deficient' or 'idiopathic short stature' and characterized by low serum concentrations of IGF-I and IGFBP-3 may, in fact, be homozygous or heterozygous for ALS mutations.
In general, the phenotype may be described as modest short stature, typically in the -2 to -3 SD range, accompanied by low serum concentrations of IGF-I and IGFBP3 , in the face of normal GH stimulation tests. Often, the low serum concentrations of IGF-I and IGFBP-3 appear to be out of proportion to the relatively minor degree of growth retardation. In particular, the extremely low serum concentrations of IGFBP-3 provide a diagnostic clue to the possibility of an ALS defect as, in general, serum levels of IGFBP-3 are less impacted than those of IGF-I in $\mathrm{GH}$ deficiency and idiopathic short stature. Failure of the patient to respond to GH therapy, either by accelerated growth or by substantive increases in serum levels of IGFI and IGFBP-3, provides further support for a presumptive diagnosis of ALS deficiency. High levels of insulin, a common finding in ALS-deficient patients, may also be useful to characterize these patients.

\section{Conclusions}

In summary, human ALS deficiency, the first monogenic defect involving an IGFBF, represents a unique condition in which the lack of ALS proteins results in the disruption of the entire IGF circulating system. In the cases of IGF-I and IGFBP-3, the inability for ternary complex formation seems to make these proteins unstable with a reduced half-life. Despite a profound circulating IGF-I deficiency, together with low levels of IGF-II, free IGF-I, bioactive IGF-I and IGFBP-1, -2 and -3, ALS deficiency has only a mild impact on postnatal growth. Perhaps the preserved expression of locally produced IGF-I under the stimulation of normal or even increased GH levels might be responsible for the preservation of linear growth near or within normal limits (fig. 2). Besides the effect on growth, the marked IGF-I deficiency observed in human ALS deficiency has other remarkable effects. The importance of IGF-I on the regulation of carbohydrate metabolism is suggested by insulin insensitivity present in almost all ALS-deficient patients in whom this has been investigated. Considering the opposite effects of GH and IGF-I on glucose internalization mediated by insulin, it is not obvious whether the insulin insensitivity is the result of a GH increase, IGF-I reduction, or the combination of both. Another common clinical finding associated with ALS deficiency is a delay in the onset of puberty, observed in half of the male patients. As delayed puberty is a common finding in IGF-I-deficient patients of different etiologies, it has been proposed that circulating IGF-I levels may represent a peripheral signal for the activation of the hypo- 
Fig. 2. GH acts on both liver and extrahepatic tissues. After associating with a homodimeric GHR complex, Janus-family tyrosine jinase 2 (JAK2) is recruited, with the resulting activation of the phosphoinositide-3 kinase (PI3K)/AKT, Ras/MAPK (mitogen-activated protein kinase) and the signal transducer and activator of transcription type 5b (STAT5b) pathways. STAT5b seems to be the crucial mediator of GH-induced IGF1, IGFBP3 and IGFALS gene transcription, resulting in IGF-I, IGFBP-3 and ALS synthesis, associated in a $150-\mathrm{kDa}$ circulating complex. When the IGFALS gene is mutated $\left(\right.$ IGFALS $\left.S^{-/-}\right)$, ternary complexes are not formed and levels of IGF-I and IGFBP-3 are reduced in the circulation. In extrahepatic tissues, even in IGFALS ${ }^{-/-}$cells, IGF-I and IGFBP-3 are normally expressed and they may act normally by paracrine or autocrine mechanisms.

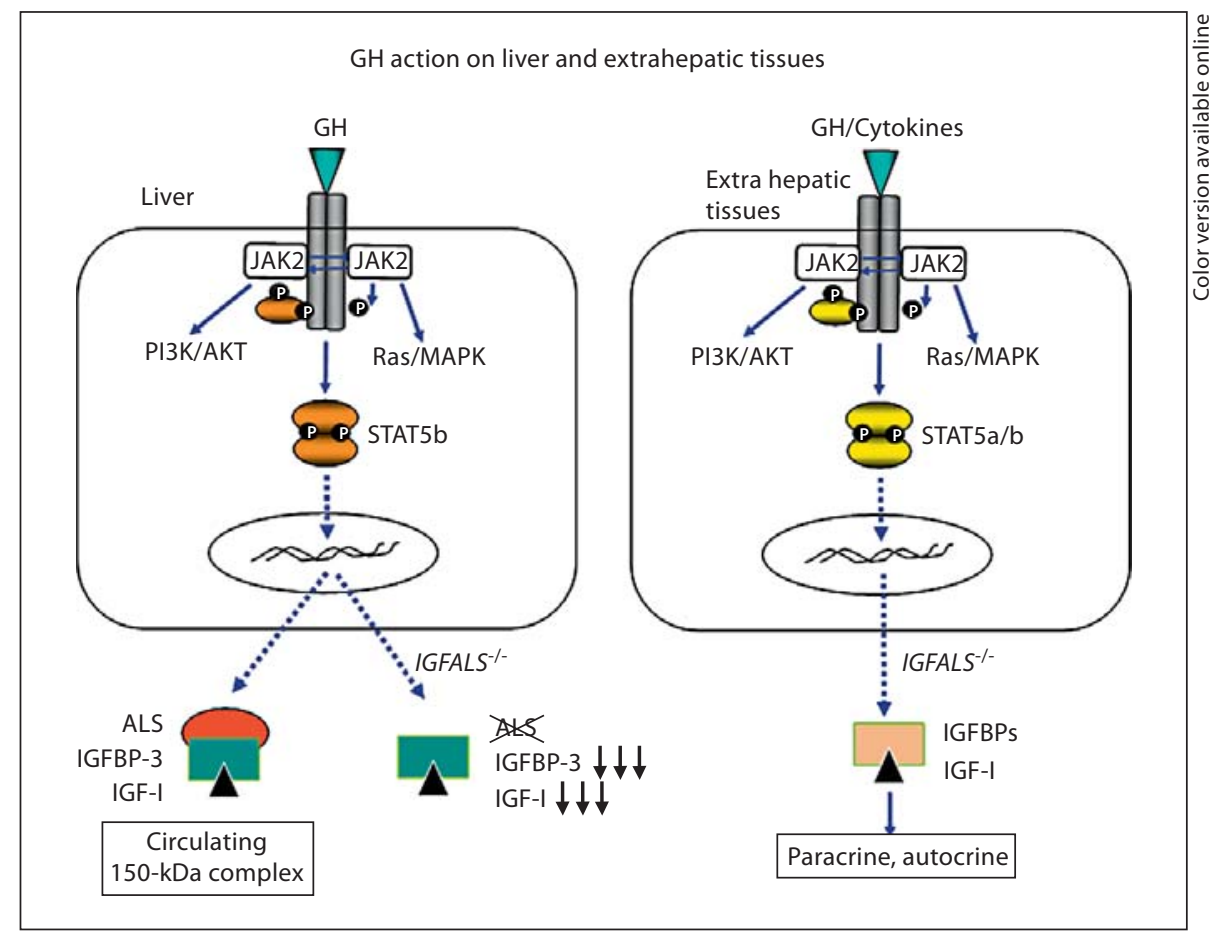

thalamic pulse-generator of gonadotrophic secretion [65]. A delay in bone mineralization has been reported in some, but not all ALS-deficient patients, suggesting that chronic circulating IGF-I deficiency may be involved in a reduced apposition of calcium on the growing cartilage. However, the underlying mechanism responsible for this alteration is not fully understood.

Since the original report of human ALS deficiency in early 2004, a surprising number of patients have been diagnosed with this condition. In addition, the finding of homozygous and compound heterozygous mutations in the IGFALS gene in apparently nonconsanguineous families suggests that mutations in this gene may be relatively frequent. Considering that when a new pathological condition is described, usually the more severe cases are first reported, it is quite likely that less severe cases of ALS deficiency, resulting from less detrimental gene mutations affecting both IGFALS alleles or even 1 severe gene mutation in heterozygosis, may in time be characterized in children with poor growth.

\section{Acknowledgments}

We are grateful to the children, their parents and colleagues who made this study possible. H.M.D. and H.G.J. were supported by grants from the Agencia Nacional de Promoción Científica y

Tecnológica (BID 1201/OC-AR PICT-2003 No. 05-14354) and an Independent Research Grant from Pfizer Global Pharmaceutical. C.C.-H. received grants from Growth Foundation, UK and Novo Nordisk Educational grant. H.A.v.D. was partially supported by a grant from Novo Nordisk.

The International ALS Collaberative Group are Paula A. Scaglia and Sonia V. Bengolea (Buenos Aires, Argentina); Aida Lteif and Salman Kirmani (Rochester, Minn., USA); Farid H. Mahmud (London, Canada); Jan Frystyk (Aarhus, Denmark); Ad Hermus, T.B. Twickler and Marlies J.E. Kempers (Nijmegen, The Netherlands); Vicente Barrios and Gabriel Á. Martos-Moreno (Madrid, Spain); Alessia David (London, UK); and Stephen Rose (Birmingham, UK).

References

Horm Res 2009;72:129-141
1 Samani AA, Yakar S, LeRoith D, Brodt P: The role of the IGF system in cancer growth and metastasis: overview and recent insights. Endocr Rev 2007;28:20-47.

2 Liu JP, Baker J, Perkins AS, Robertson EJ, Efstratiadis A: Mice carrying null mutations of the genes encoding insulin-like growth factor I (Igf-1) and type 1 IGF receptor (Igf1r). Cell 1993;75:59-72.

- 3 Woods KA, Camacho-Hübner C, Savage MO, Clark AJL: Intrauterine growth retardation and postnatal growth failure associated with deletion of the insulin-like growth factor I gene. N Engl J Med 1996;335:13631367. 
-4 Walenkamp MJ, Karperien M, Pereira AM, Hilhorst-Hofstee Y, van Doorn J, Chen JW, Mohan S, Denley A, Forbes B, van Duyvenvoorde $\mathrm{HA}$, van Thiel SW, Sluimers CA, Bax JJ, de Laat JA, Breuning MB, Romijn JA, Wit JM: Homozygous and heterozygous expression of a novel insulin-like growth factor-I gene mutation. J Clin Endocrinol Metab 2005;90:2855-2864.

5 Bennet A, Wilson DM, Liu F, Nagashima R, Rosenfeld RG, Hintz RL: Levels of insulinlike growth factors I and II in human cord blood. J Clin Endocrinol Metab 1983;57: 609-612.

-6 Rosenfeld RG, Wilson DM, Lee PD, Hintz RL: Insulin-like growth factors I and II in evaluation of growth retardation. J Pediatr 1986;109:428-433.

7 Boisclair YR, Rhoads RP, Ueki I, Wang J, Ooi GT: The acid-labile subunit (ALS) of the 150 kDa IGF-binding protein complex: an important but forgotten component of the circulating IGF system. J Endocrinol 2001;170: 63-70.

$>8$ Rosenfeld RG, Belgorosky A, CamachoHübner C, Savage MO, Wit JM, Hwa V: Defects in growth hormone receptor signaling. Trends Endocrinol Metab 2007;18:134-141.

$\checkmark 9$ Domené HM, Bengolea SV, Martínez AS, Ropelato MG, Pennisi P, Scaglia P, Heinrich JJ, Jasper HG: Deficiency of the circulating insulin-like growth factor system associated with inactivation of the acid-labile subunit gene. N Engl J Med 2004;350:570-577.

10 Janosi JB, Ramsland PA, Mott MR, Firth SM, Baxter RC, Delhanty PJ: The acid-labile subunit of the serum insulin-like growth factor-binding protein complexes: structural determination by molecular modeling and electron microscopy. J Biol Chem 1999;274: 23328-23332.

- 11 Janosi JB, Firth SM, Bond JJ, Baxter RC, Delanthy PJ: N-linked glycosilations and sialylations of the acid labile subunit. J Biol Chem 1999;74:5292-5298.

-12 Arquier N, Géminard C, Bourouis M, Jarretou G, Honegger B, Paix A, Léopold P: Drosophila ALS regulates growth and metabolism through functional interaction with insulin-like peptides. Cell Metab 2008;7: 333-338.

-13 Haluzik M, Yakar S, Gavrilova O, Setser J, Boisclair Y, LeRoith D: Insulin-resistance in the liver-specific IGF-I gene-deleted mouse is abrogated by deletion of the acid-labile subunit of the IGF-binding protein-3 complex. Diabetes 2003;52:2483-2488.

- 14 Ueki I, Ooi GT, Tremblay ML, Hurst KR, Bach LA, Boisclair YR: Inactivation of the acid labile subunit gene in mice results in mild retardation of postnatal growth despite profound disruptions in the circulating insulin-like growth factor system. Proc Natl Acad Sci USA 2000;97:6868-6873.
5 Yakar S, Rosen CJ, Beamer, Ackert-Bicknell CL, Wu Y, Liu JL, Ooi GT, Setser J, Frystyk J, Boisclair YR, LeRoith D: Circulating levels of IGF-I directly regulate bone growth and density. J Clin Invest 2002;110:771-781.

16 Niklasson A, Ericson A, Fryer JG, Karlberg J, Larwence C, Karlberg P: An update of the Swedish reference standards for weight, length and head circumference at birth for given gestational age (1977-1981). Acta Paed Scand 1991;80:756-762.

17 Sobradillo B, Aguirre A, Aresti U, Bilbao A Fernández-Ramos C, Lizárragta A, Lorenzo H, Madariaga L, Rica I, Ruiz I, Sánchez E, Santamaría C, Serrano JM, Zabala A, Zurimendi B, Hernández M: Curvas y Tablas de Crecimiento (Estudios Longitudinal y Transversal). Bilbao, Fundación Faustino Orbegozo Eizaguirre, 2002, pp 1-36.

18 Carrascosa Lezcano A, Ferrández Longás A, Yeste Fernández D, García-Dihinx Villano va J, Romo Montejo A, Copil Copil A, Almar Mendoza J, Salcedo Abizanda S, Gussinyé Canadell M, Baguer Mor L: Estudio transversal español de crecimiento 2008. Parte I: valores de peso y longitud en recién nacidos de 26-42 semanas de edad gestacional. An Pediatr (Barc) 2008;68:544-551.

19 Wikland KA, Luo ZC, Niklasson A, Karlberg J: Swedish population-based longitudinal reference values from birth to 18 years of age for height, weight and head circumference. Acta Paediatr 2002;91:739-754.

20 Domené HM, Martínez AS, Frystyk J, Bengolea SV, Ropelato MG, Scaglia PA, Chen JW, Heuck C, Wolthers OD, Heinrich JJ, Jasper HG: Normal growth spurt and final height despite low levels of all forms of circulating IGF-I in a patient with ALS deficiency. Horm Res 2007;67:243-249.

21 Domené HM, Scaglia PA, Lteif A, Mahmud FH, Kirmani S, Frystyk J, Bedecarrás P, Gutiérrez M, Jasper HG: Phenotypic effect of null and haploinsufficiency of acid-labile subunit in a family with two novel IGFALS gene mutations. J Clin Endocrinol Metab 2007;92:4444-4450.

-22 Heath KE, Argente J, Barrios V, Pozo J, DíazGonzález F, Martos-Moreno GA, Caimari M, Gracia R, Campos-Barros A: Primary acid-labile subunit deficiency due to recessive IGFALS mutations results in postnatal growth deficit associated with low circulating insulin growth factor (IGF)-I, IGF binding protein-3 levels, and hyperinsulinism. J Clin Endocrinol Metab 2008;93:1616-1624.

$\checkmark 23$ van Duyvenvoorde HA, Kempers MJE, Twickler TB, van Doorn J, Gerver WJ, Noordam C, Losekoot M, Karperien M, Wit JM, Hermus ARMM: Homozygous and heterozygous expression of a novel mutation of the acid-labile subunit. Eur J Endocrinol 2008. 159:113-120.
24 Fofanova-Gambetti OV, Hwa V, Kirsch S, Pihoker C, Chiu HK, Derr MA, Rosenfeld RG: Three novel IGFALS gene mutations resulting in total ALS and severe circulating IGFI/IGFBP-3 deficiency in children of different ethnic origins. Horm Res 2009;71:100-110.

25 Suwanichkul A, Boisclair YR, Olney RC, Durham SK, Powell DR: Conservation of a growth hormone-responsive promoter element in the human and mouse acid-labile subunit genes. Endocrinology 2000;141: 833-838.

26 David A, Rose S, Miraki-Moud F, Metherell L, Clark A, Savage M, Camacho-Hübner C: Acid-labile subunit gene mutations: clinical, biochemical and molecular study in two unrelated families. 47th Annual Meeting of the European Society for Paediatric Endocrinology, Istanbul, Turkey, September 20-23, 2008. Horm Res 2008;70(suppl 1):31.

27 Hwa V, Haeusler G, Pratt KL, Little BM, Frisch H, Koller D, Rosenfeld RG: Total absence of functional acid labile subunit, resulting in severe insulin-like growth factor deficiency and moderate growth failure. J Clin Endocrinol Metab 2006;91:1826-1831.

$>28$ Den Dunnen J, Antonarakis SE: Nomenclature for the description of human sequence variations. Hum Genet 2001;109:121-124

29 Firth SM, Yan X, Baxter RC: D413N mutation of the acid-labile subunit, a component of endocrine IGF complexes, causes defects in secretion and complex formation (abstract P2-651). Proc 90th Ann Meet Endocr Soc, San Francisco, 2008, p 562.

30 Baxter RC, Martin JL, Beniac VA: High molecular weight insulin-like growth factor binding protein complex: purification and properties of the acid-labile subunit from human serum. J Biol Chem 1989;264:1184311848.

-31 Baxter RC: Circulating levels and molecular distribution of the acid-labile (alfa)-subunit of the high molecular weight insulin-like growth factor-binding protein complex. J Clin Endocrinol Metab 1990;70:1347-1353.

>32 Guler HP, Zapf J, Schmid C, Froesch ER: Insulin-like growth factors I and II in healthy man: estimations of half-lives and production rates. Acta Endocrinol (Copenh) 1989; 121:753-758.

-33 Zapf J, Hauri C, Futo E, Hussain M, Rutishauser J, Maack CA, Froesch ER: Intravenously injected insulin-like growth factor (IGF) I/IGF binding protein-3 complex exerts insulin-like effects in hypophysectomized, but not in normal rats. J Clin Invest 1995;95:179-186.

34 Payet LD, Firth SM, Baxter RC: The role of the acid-labile subunit in regulating insulinlike growth factor transport across human umbilical vein endothelial cell monolayers. J Clin Endocrinol Metab 2004;89:2382-2389.

>35 Holman SR, Baxter RC: Insulin-like growth factor binding protein-3:factors affecting binary and ternary complex formation. Growth Regul 1996;6:42-47. 
- 36 Ning Y, Schuller AGP, Bradshaw S, Rotwein P, Ludwig T, Frystyk J, Pintar JE: Diminished growth and enhanced glucose metabolism in triple knockout mice containing mutations of insulin-like growth factor binding protein-3, -4, and -5. Mol Endocrinol 2006;20: 2173-2186.

- 37 Böni-Schnetzler M, Schnid C, Mary JL, Zimmerli B, Meier PJ, Zapf J, Schwander J, Froesch ER: Insulin regulates the expression of the insulin-like growth factor binding protein 2 mRNA in rat hepatocytes. Mol Endocrinol 1990;4:1320-1326.

- 38 Ooi GT, Tseng LY, Rechler MM: Post-transcriptional regulation of insulin-like growth factor binding protein-2 mRNA in diabetic rat liver. Biochem Biophys Res Commun 1992;189:1031-1037.

-39 Frystyk J: Free insulin-like growth factors measurements and relationships to growth hormone secretion and glucose homeostasis. Growth Horm IGF Res 2004;14:337-375.

-40 Smith WJ, Nam TJ, Underwood LE, Busby WH, Celnicker A, Clemmons DR: Use of insulin-like growth factor-binding protein-2 (IGFBP-2), IGFBP-3, and IGF-I for assessing growth hormone status in short children. J Clin Endocrinol Metab 1993;77:1294-1299.

-41 Clemmons DR, Snyder DK, Busby WH Jr: Variables controlling the secretion of insulin-like growth factor binding protein-2 in normal human subjects. J Clin Endocrinol Metab 1991;73:727-733.

-42 Ten S, Maclaren N: Insulin resistance syndrome in children. J Clin Endocrinol Metab 2004;89:2526-2539.

-43 Reaven GM, Chen YD, Hollenbeck CB, Sheu WH, Ostrega D, Polonsky KS: Plasma insulin, C-peptide, and proinsulin concentrations in obese and nonobese individuals with varying degrees of glucose tolerance. J Clin Endocrinol Metab 1993;76:44-48.

-44 Matthews DR, Hosker JP, Rudenski AS, Naylor BA, Treacher DF, Turner RC: Homeostasis model assessment: insulin resistance and $\beta$-cell function from fasting plasma glucose and insulin concentrations in man. Diabetologia 1985;28:412-419.
45 Maddux BA, Chan A, De Filippis EA, Mandarino LJ, Goldfine ID: IGF-binding protein-1 levels are related to insulin-mediated glucose disposal and are a potential serum marker of insulin resistance. Diab Care 2006;29:1535-1537.

46 Houssay BA: The hypophysis and metabolism. N Engl J Med 1936;214:961-986.

47 Jørgensen JO, Krag M, Jessen N, Nørrelund $\mathrm{H}$, Vestergaard ET, Møller N, Christiansen JS: Growth hormone and glucose homeostasis. Horm Res 2004;62(suppl 3):51-55.

48 Randle PJ: Regulatory interactions between lipids and carbohydrates: the glucose fatty acid cycle after 35 years. Diab Metab Rev 1998; 14:263-283.

49 Segerlantz M, Bramnert M, Manhem P, Laurila $\mathrm{E}$, Groop LC: Inhibition of the rise in FFA by Acipimox partially prevents GH-induced insulin resistance in $\mathrm{GH}$-deficient adults. J Clin Endocrinol Metab 2001;86: 5813-5818.

50 Dominici FP, Argentino DP, Muñoz MC, Miquet JG, Sotelo AI, Turyn D: Influence of the crosstalk between growth hormone and insulin signalling on the modulation of insulin sensitivity. Growth Horm IGF Res 2005; 15:324-336

51 Nilsson L, Binart N, Bohlooly-Y M, Bramnert M, Egecioglu E, Kindblom J, Kelly PA, Kopchick JJ, Ormandy CJ, Ling C, Billig H: Prolactin and growth hormone regulate adiponectin secretion and receptor expression in adipose tissue. Biochem Biophys Res Commun 2005;331:1120-1126.

-52 Kralisch S, Klein J, Lossner U, Bluher M, Paschke R, Stumvoll M, Fasshauer M: Hormonal regulation of the novel adipocytokine visfatin in 3T3-L1 adipocytes. J Endocrinol 2005;185:R1-R8.

53 Venkatesan N, Davidson MB: Insulin resistance in rats harboring growth hormone-secreting tumors: decreased receptor number but increased kinase activity in liver. Metabolism 1995;44:75-84.

54 Yuen KCJ, Dunger DB: Impact of treatment with recombinant human GH and IGF-I on visceral adipose tissue and glucose homeostasis in adults. Growth Horm IGF Res 2006; 16:S55-S61.

55 Clemmons DR: The relative roles of growth hormone and IGF-1 in controlling insulin sensitivity. J Clin Invest 2004;113:25-27.
56 Yakar S, Liu JL, Fernandez AM, Wu Y, Schally AV, Frystyk J, Chernausek SD, Mejia W, Le Roith D: Liver-specific IGF-1 gene deletion leads to muscle insulin insensitivity. Diabetes 2001;50:1110-1118.

>57 Sjögren K, Wallenius K, Liu JL, Bohlooly-Y M, Pacini G, Svensson L, Törnell J, Isaksson OG, Ahrén B, Jansson JO, Ohlsson C: Liverderived IGF-I is of importance for normal carbohydrate and lipid metabolism. Diabetes 2001;50:1539-1545.

58 Clemmons DR: Role of insulin-like growth factor I in maintaining normal glucose homeostasis. Horm Res 2004;62(suppl 1):7782.

59 Dohm GL, Elton CW, Raju MS, Mooney ND, DiMarchi R, Pories WJ, Flickinger EG, Atkinson SM Jr, Caro JF: IGF-1-stimulated glucose transport in human skeletal muscle and IGF-1 resistance in obesity and NIDDM. Diabetes 1990;39:1028-1032.

60 Soos MA, Whittaker J, Lammers R, Ullrich A, Siddle K: Receptors for insulin and insulin-like growth factor-I can form hybrid dimers: characterisation of hybrid receptors in transfected cells. Biochem J 1990;270:383390.

61 Turner HE, Wass JA: Modern approaches to treating acromegaly. QJM 2000;93:1-6.

62 Beamer WG, Donahue LR, Rosen CJ, Baylink DJ: Genetic variability in adult bone density among inbred strains of mice. Bone 1996;18:397-403.

63 Hildebrand T, Laib A, Muller R, Dequeker J, Ruegsegger P: Direct three-dimensional morphometric analysis of human cancellous bone: microstructural data from spine, femur, iliac crest, and calcaneus. J Bone Miner Res 1999;14:1167-1174.

64 Domené HM, Bengolea SV, Jasper HG, Boisclair YR: Acid-labile subunit deficiency: phenotypic similarities and differences between human and mouse. J Endocrinol Invest $2005 ; 28: 43-46$.

65 Hiney JK, Ojeda SR, Dees WL: Insulin-like growth factor I: a possible metabolic signal involved in the regulation of female puberty. Neuroendocrinology 1991;54:420-423. 